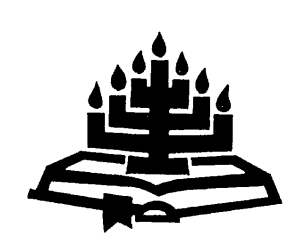

\title{
Verlossing: van Pelagius tot Joseph Smith
}

\author{
H.F. van Wyk \\ Gereformeerde Kerk Bloemhof/Christiana \\ BLOEMHOF \\ E-pos: hennie@ssplus.co.za
}

Abstract

\section{Salvation: from Pelagius to Joseph Smith}

Every Christian church believes that she is a true church and proclaims that man can be saved and has eternal life. This dogma of salvation is usually based on the Bible as the Word of God. Mormons claim that Joseph Smith, founder and first president of the Church of Jesus Christ of Latter Day Saints, received a divine message to restore the church that Jesus had started.

In studying the plan of salvation the Mormons proclaim it is quite clear that that way of salvation was not restored in their church, but that it followed a pattern of false doctrine that was revealed time and again in history.

The core of their preaching of salvation is that man has the free will to choose his own salvation. Mormons are not the first to preach this message. This article will show that Pelagius oistykated the free will of man. In the Reformation the Anabaptists preached the same message, being a third movement next to the reformed and Roman Catholic believes. The Anabaptists became part of the churches of the Netherlands and at the Synod of Dordt the theology of the free will was rejected and answered.

The dogma of the free will of man did not end at this Synod: 150 years later John Wesley preached the same message of salvation during his and Whitefield's campaigns at the dawn of the nineteenth century in the USA.

During this time Joseph Smith started to seek the true church and founded the Mormon Church. Although his theology differs quite strongly from the Methodist Church in which he grew up, the core of the way of salvation is the same: man has free will in choosing his salvation. 


\section{Opsomming}

\section{Verlossing: van Pelagius tot Joseph Smith}

Elke Christelike kerk glo dat sy 'n ware kerk is en verkondig dat die mens verlos kan word om ewig te leef. Hierdie verlossingsboodskap is gewoonlik gewortel in die Bybel as openbaringsbron van God. Die Mormone beweer dat Joseph Smith, stigter en eerste president van die Kerk van Jesus Christus van die Heiliges van die Laaste Dae, 'n goddelike opdrag ontvang het om die kerk te herstel na die kerk soos wat Jesus Christus dit tydens sy lewe op aarde gestig het.

In die studie van die Mormoonse verlossingsleer is dit duidelik dat die kerk nie werklik vervals is en herstellend herstig is nie, maar dat die verlossingsleer dogma-histories 'n duidelike lyn van dwaling en weerlegging volg.

Die kern van die verlossingsleer van die Mormone is dat die mens die vrye wil het om sy eie verlossing te kies. Hulle is nie die eerstes wat hierdie boodskap verkondig nie. In hierdie artikel word aangetoon hoedat Pelagius reeds die vrye wil van die mens verkondig het. Tydens die Reformasie het die Anabaptiste dieselfde boodskap verkondig en hulle het aanvanklik naas die reformatore bestaan. Gaandeweg het hulle deel van veral die Nederlandse kerke geword, totdat die sinode van Dordrecht hierdie dwaling uitgewys en nie net verwerp het nie, maar ook geantwoord het.

Hiermee is die dogma van die vrye wil nie besweer nie, maar dit word weer 150 jaar later deur John Wesley verkondig. Hierdie is ook die boodskap van Wesley en Whitefield tydens hulle evangelisasieveldtogte in die Verenigde state van Amerika aan die begin van die negentiende eeu.

Dit is in hierdie tyd dat Joseph Smith se soeke van die regte kerk plaasgevind het en hy die Mormoonse kerk gestig het. Alhoewel daar baie verskil is met die Metodiste Kerk, die kerk waarin hy opgegroei het, is die verlossingsboodskap in wese dieselfde: die mens het die vrye wil om sy saligheid te soek en te verkry.

\section{Inleiding}

Elke godsdiensbeweging se teologie het 'n ontwikkelingsgeskiedenis. Om die verlossingsteologie van Joseph Smith, stigter van die Kerk van Jesus Christus van die Heiliges van die Laaste Dae (Mormone) reg te verstaan, moet gekyk word na die godsdienstige agtergrond en die ontwikkeling van die dogma van sy verlossingsleer. In 
hierdie artikel gaan vanuit die gereformeerde gesigspunt die historiese lyn aangetoon word vanaf Pelagius tot by Joseph Smith.

\section{Pelagius}

Pelagius ( \pm 354-440) was 'n monnik afkomstig van die Britse eilande. Sy siening oor sonde het daartoe gelei dat hy die absolute noodsaaklikheid van God se genade in Christus se verlossing misken het. Hy het geglo dat die mens deur sy eie werke (onderhouding van die wet) verlos kon word (Berkhof, 1975:205).

Pelagius het nooit die werking van God in die verlossing van die mens misken nie, maar daar is twee punte wat sterk uitstaan in sy verlossingsleer (Berkhof, 1975:206):

- Die mens is nie totaal verdorwe nie en het die keuse of hy goed of sleg wil doen. Hy verwerp die gedagte van die erfsonde en wou nie glo dat iemand verantwoordelik gehou sou word vir die sonde van 'n ander nie (Schulze, 1978:126). 'n Sondelose bestaan van die mens is, ten spyte van die sondeval, tog moontlik. Die mens besit onvoorwaardelike vryheid en verantwoordelikheid (Schulze, 1978:127).

- Die verkondiging van die evangelie sowel as die voorbeeld van Christus maak ' $n$ appèl op die mens sodat die mens tot saligheid moet kom. Dit is alles moontlik vir die mens wat uit die natuur en die prediking van Christus leer. Genade werk nie direk en onmiddellik in op die wil van die mens nie, maar op sy begrip, wat vergestalt word in die wil van die mens om in God te glo (Schulze, 1978:128).

Augustinus antwoord Pelagius deur die leer van die erfsonde, naamlik dat die mens met sonde belaai is selfs vóór sy geboorte (Berkouwer \& Toornvliet, 1949:42; Calvyn, 1986:357).

Pelagius was 'n prominente teoloog wat die vrye wil van die mens ten opsigte van sy eie verlossing verkondig het. Vir die doel van hierdie artikel is dit nie belangrik om Pelagius se breë invloed te beskryf nie. Hier sal net aangetoon word watter invloed hy op die denke van Jakob Arminius gehad het asook watter reaksie dit aan die begin van die sewentiende eeu in die Nederlande ontlok het. 


\section{Hervorming}

Tot en met die Hervorming is die teologie en veral die verlossingsleer deur die Rooms Katolisisme oorheers. Wie 'n ander verlossingsleer verkondig het, is eenvoudig veroordeel en tereggestel.

John Wycliffe ( $\pm 1320-1384)$ het die Bybel in Engels vertaal en begin leer dat die mens deur genade verlos word - in teenstelling met die Rooms Katolieke teologie. Hy is in 1415 verban, sy vertaling as onwettig verklaar en sy boeke is verbrand. Twaalf jaar na sy dood is sy beendere opgegrawe en ook verbrand (Biggs, 1965:157).

Girolamo Savonarola was 'n priester in Florence. Hy is gemartel, opgehang en in 1498 verbrand omdat hy pous Aleksander VI oor die middelaarskap van Jesus teëgegaan het (De Jong, 1980:151).

Johannes Hus ( \pm 1369-1414) het die geskrifte van John Wycliffe $( \pm 1330-1384)$ bestudeer en ook in Bohemië gepreek dat Christus die enigste Middelaar is deur wie die mens verlos kan word. Johannes Hus wou die kerk hervorm deur terug te gaan na die Skrif - hy het selfs die Bybel in Engels vertaal. Hus het die kerklike organisasie gekritiseer asook die onskriftuurlike mag van die pous en sterf in 1414 op die brandstapel (d'Assonville, 1992:91).

\subsection{Die hervormers}

Hierdie artikel wil geen aanspraak maak om die geskiedenis van die Hervorming volledig weer te gee nie. Aangesien die fokus op die verlossingsleer is, gaan slegs enkele sake genoem word.

Verskeie lande het hervormers opgelewer. Dit is egter opvallend dat dit nie die geval met die Nederlande is nie. 'n Nederlandse filosoof wat egter 'n groot invloed op die Reformasie gehad het, was Desiderius Erasmus.

\subsubsection{Desiderius Erasmus}

Desiderius Erasmus (1466-1536) was 'n Nederlandse Humanis. 1 Sy geskrifte en kontak met Martin Luther het die idee laat ontstaan dat hy wel deel van die Hervorming was (Den Boer, 2004:57). Erasmus

$1 \quad$ Humanis het in die sestiende eeu nie ateïsme geïmpliseer soos wat dit in die $21 \mathrm{e}$ eeu die geval is nie. Dit het slegs beteken dat daar ' $n$ hernude belangstelling in die wetenskap en kuns was (HAT, 1988:422). Hier verwys dit na enige persoon wat die Klassieke tale en geskrifte bestudeer. 
het egter nooit met die Rooms-Katolieke Kerk gebreek nie (Cereghin, 2006). As kenner van die Klassieke tale en veral Grieks, het hy reeds lank voor die Reformasie aan die samestelling van die Griekse teks van die Nuwe Testament gewerk. Die eerste uitgawe het in 1516 verskyn en die laaste in 1522 (Elliott, 2005). Dit is daarna weer bygewerk en herdruk.

Hy het baie sterk standpunt ingeneem oor die feit dat die mens oor 'n vrye wil beskik om te glo al dan nie. Oor hierdie saak was hy in debat met Martin Luther, maar hulle het nooit tot 'n vergelyk gekom nie (Den Boer, 2004:61).

Die invloed van Erasmus in Europa en Groot Brittanje kan maklik onderskat word. Hy het 'n groot invloed gehad op onder andere Zwingli, die Switserse hervormer (Lindsay, 1964:10), wat weer ' $n$ invloed op die Anabaptiste gehad het.

\subsubsection{Ulrich Zwingli}

Zwingli is op 1 Januarie 1484 in Wildhaus, Switserland gebore en het op die slagveld by Kappel am Albis op 11 Oktober 1531 gesterf. $\mathrm{Hy}$ het in die Rooms-Katolieke Kerk grootgeword en het in 1506 priester in Glarus geword. Gedurende die tien jaar wat hy daar priester was, het hy 'n deeglike studie van Grieks en Hebreeus gemaak. Hy het Erasmus persoonlik ontmoet en ook sy geskrifte bestudeer (d'Assonville, 1992:110). Daar was nie baie teologiese werke in Glarus beskikbaar nie en daarom het hy hom baie meer op die lees van die Bybel in die grondtekste toegelê.

Aanvanklik het hy as pastoor kapelaansdiens in die weermag gedoen. Eers in 1519 is hy toegelaat om te begin preek ${ }^{2}$ (De Jong, 1980:172). Die ondersoek van die Bybel het hom tot meer vrae ten opsigte van die Roomse leer gelei. Vanaf 1519 het hy openlik die Roomse praktyke (onder andere die aflaat) in sy moedertaal bevraagteken, soos Luther. In 1523 het hy sy 67 stellinge teen gebruike van die Roomse kerk uitgereik (De Jong, 1980:173).

Zwingli het ook die Bybel in Duits vertaal, wat as die Froschauer Bibel of die Zürich-Bybel bekend staan; dit is tussen 1524 en 1531 gedruk. Hierdie vertaling het die Bybel toeganklik vir die volk gemaak. Dit het egter ook vir die Anabaptiste die geleentheid gegee

2 De Jong maak hier 'n onderskeid tussen die werk van 'n pastoor en 'n preekpriester. 
om 'n eie interpretasie van die Bybel te maak. Uiteindelik moes Zwingli sy leer teen die Rooms-Katolieke Kerk en die Anabaptiste verdedig (De Jong, 1980:181). Sy prediking het daarvan getuig dat dit vir hom belangrik is dat die Woord van die Here toeganklik moet wees vir die gewone mens sodat hulle sinvol deel kan hê aan die erediens en self die Skrif kon bestudeer.

\subsubsection{Samevattend}

Erasmus se aandeel aan die Hervorming was groot daarin dat hy 'n grondteks in Hebreeus en Grieks daargestel het wat deur priesters in die kerk, soos Luther en Zwingli, in die bestudering van die Skrif gebruik is. Hierdie studie het tot die bevraagteken en weerlegging van die Roomse verlossingsteologie gelei.

Die vertaling van die Bybel deur die Hervormers het die evangelie meer toeganklik gemaak vir nie-teoloë. Dit het 'n duidelike invloed gehad op die ontstaan van die Anabaptiste met 'n derde verlossingsleer naas dié van die Rooms-Katolieke Kerk en die Reformatore soos Luther, Zwingli en Calvyn.

\section{Die Anabaptiste}

By historici is nie eenstemmigheid oor die rol wat die Anabaptiste tydens die Reformasie gespeel het nie. Bosman (1987:2) noem hulle 'n "revolusionêre sekte", 'n afleiding wat hy maak uit die voorwoord van Calvyn (1986:108) se Institusie, gerig aan koning Frans van Frankryk. Calvyn noem hulle "deugniete" wat tweespalt en konflik oor die dogma aanblaas. Daarteenoor meen Estep (1975:3) dat die Anabaptiste bloot 'n groep gelowiges was wat deur Europa getrek het op soek na vryheid.

\subsection{Ontstaan}

Daar is verskillende standpunte oor die ontstaan van die Anabaptiste. Anderson (2006) sien die ontstaan van die Anabaptiste in die tyd van Johannes die Doper. Hy voer aan dat daar sedert die tyd van Johannes die Doper Anabaptiste was en dat die Anabaptiste voor die Reformasie van Wycliffe en Luther, naas die Katolieke Kerk, aktief was. Hy meld dat die Anabaptiste sedert die begin van die Nuwe-Testamentiese kerkgeskiedenis bestaan het as ' $\mathrm{n}$ groep mense wat kerkwees (soos hulle dit vanuit die Nuwe Testament verstaan het) ten volle wou uitleef. Die kern van sy betoog is dat daar geen dogma is wat die mens verlos nie, maar dat dit gaan oor die keuse wat die mens maak om die genade van God te aanvaar. 
Aan die ander kant is daar ook geskiedskrywers wat die ontstaan van die Anabaptiste aan die Reformasie koppel. Een van Zwingli se studente was Conrad Grebel. Grebel het onder andere Grieks bestudeer en was ook onder die invloed van Erasmus se Humanisme en sy siening oor die vrye wil van die mens (Den Boer, 2004:61). In 1522 het Grebel Zwingli se idees rondom die Reformasie aanvaar. In 1525 het hy egter met Zwingli gebreek, aangesien Zwingli, volgens Grebel, nie "ver genoeg" hervorm het nie (Estep, 1975:10).

Littell (1952:79) (self 'n Anabaptis) is van mening dat die Reformatore nie die moed van hulle oortuiging gehad het om radikaal met die verlede (die Roomse tradisie) te breek nie. Die Anabaptiste het volgens hom wel die radikale breuk gemaak. Hy stel dit duidelik dat die Anabaptisme nie gesien mag word as 'n variasie van die Protestantisme nie, maar as 'n derde groep naas die Katolieke en die Protestante.

Op 21 Januarie 1525 het 'n groepie mans aan huis van Felix Mans vergader. Gedurende hierdie byeenkoms het hulle ernstig tot God gebid vir leiding oor wat hulle te doen staan in hulle geloofslewe. Grebel het vir Blaurock ('n priester van Zürich) gedoop waarna Blaurock weer die ander gedoop het (Estep, 1975:11). Hulle het geglo dat verlossing moontlik is deur 'n persoonlike verhouding met Christus en die doop ná die belydenis van sonde en geloof. Die bekeringsdoop was nie 'n spontane daad van hierdie groep mense nie, maar die resultaat van hulle Bybelstudie (Estep, 1975:11).

Die Anabaptiste sien self hulle oorsprong in die werk van Zwingli en dat Grebel die radikale breuk gemaak het en die "ware kerk" gestig het (Littell, 1952:79).

\subsection{Belydenis}

Vir die Anabaptiste was die Nuwe Testament gesagvol. Hulle het so streng by die prediking van die Nuwe Testament gehou dat hulle biblisisties was. Elkeen van die sake wat hulle gepreek en verkondig het, moes dit direk uit die Bybel gegrond en gestaaf het, anders is dit verwerp (Estep, 1975:15). Daar is nie werklik sprake van 'n vroeë teologie nie, maar wel van individuele standpunte (Estep, 1975:131). Daar is selfs by die moderne Anabaptiste nie eenstemmigheid oor wat aan die begin van die sestiende eeu geglo en bely is nie: 
sommiges dink dat slegs die twaalf Artikels as belydenis aanvaar is 3 (Lindsay, 1964:235). Tydens die Reformasie is hulle deur die Rooms-Katolieke Kerk bestry en Calvyn het hulle dogma verwerp (Calvyn, 1988:785).

In 1527 het die Schleitheim Confession uit die geledere van die Anabaptiste verskyn (GAMEO, 2006), wat uit sewe artikels bestaan het. Die artikels behels kortliks die volgende:

1. Die doop: Die doop word aan diegene bedien wat bekering ondergaan het en 'n nuwe lewe lei; wat werklik glo dat hulle sonde deur Jesus Christus weggeneem is en wat uit sy opstanding leef.

2. Die ban: Die ban word bedien aan diegene wat hulleself oorgegee het aan die Here, met Hom geleef het in sy gebooie, wat in die liggaam van Christus gedoop is, broers en susters in die geloof is en dan op die een of ander wyse afvallig geword het.

3. Die breek van die brood: Wie begeer om deel te hê aan die breek van die brood as herinnering aan die gebreekte liggaam van Christus en hulle wat wil drink ter herinnering aan die vergote bloed van Christus, moet vooraf deur die doop één word met die liggaam van Christus (sy gemeente) waarvan Christus die Hoof is.

4. Losmaking van die duiwel: Die gelowige mag nie deelneem aan of deel wees van die bose praktyke van die duiwel nie. Die mens is óf aan Christus óf aan die wêreld gehoorsaam.

5. Herders in die kerk: Die herders moet ooreenkomstig die reëls van Paulus regeer: hulle moet 'n goeie getuienis binne en buite die kerk hê; moet uit die Woord lees, dit verklaar en onderrig, waarsku, deel hê aan die teregwysing en ban in die gemeente, die broeders en susters lei, die brood breek en alles reël wat betrekking het op die versorging van die liggaam van Christus.

6. Die swaardmag: Die swaardmag word aan die kerk gegee. Dit is 'n opdrag van God aan die kerk, wat nie soos Christus volmaak is nie. Dit straf en dood die bose en bewaak en

3 Erasmus het ook in sy geskrifte teen die Reformasie, maar ook teen sekere persone en hulle Rooms-Katolieke teologie, verkies om by slegs een belydenis te hou: die Apostoliese Geloofsbelydenis (Den Boer, 2004:61). 
beskerm die goeie. Binne die kerk kan net die ban as God se swaardmag gebruik word.

7. Die eed: Christus verbied sy volgelinge om hoegenaamd 'n eed af te lê.

Die Anabaptiste het dus 'n bepaalde belydenis gehad en beleef, wat weerklank gekry het in verskillende denkrigtings binne die teologie. Vir hierdie artikel is dit belangrik om daarop te let dat die Anabaptisme later in die geskiedenis sterk binne die Metodisme figureer en daaruit het die Mormonisme ontstaan.

\section{Remonstrante}

Die konvent van Wesel (1568) en die Sinode van Emden (1571) het besluit dat kerke die Heidelbergse Kategismus as hulle belydenis moet onderteken (Van 't Spijker, 1987:18). Sommige gemeentes het geweier en selfs 'n alternatiewe belydenis daargestel. Die leerstellings oor die erfsonde, regverdigmaking deur die geloof alleen en die versoening in Christus is uitgelaat (Van 't Spijker, 1987:19, 20).

Jakobus Arminius (1560-1609) is op 20 Oktober 1560 in Oudewater, Utrecht, gebore. Sy vader is dood toe hy nog 'n baba was en aangesien sy moeder baie kinders gehad het om groot te maak, het sy toegelaat dat Theodorus Aemilius, 'n priester, hom aanneem en hom in Utrecht skoolopleiding laat ontvang. Hy het teologie aan die Universiteit van Leiden studeer (d'Assonville, 1992:165).

Tydens sy studie is hy deur verskeie teoloë beïnvloed. Hy het onder andere die geskrifte van Pieter Ramus ${ }^{4}$ bestudeer. Een van sy leermeesters was Johann Kolmann, 'n Calvinis. Hy het God egter as 'n tiran en 'n vervolger uitgebeeld. In 1582 het hy onder Beza, $\mathbf{5}$ die

4 Ramus (1515-1572) was 'n humanis en filosoof. Sy proefskrif se titel was: Al Aristoteles se leerstellings is vals. Hierdie, asook twee ander werke van hom, is deur die Universiteit van Parys verdoem. Sy idees het hom ook in konflik met die Rooms-Katolieke Kerk gebring. Hy het die kerk verlaat en in 1562 'n Protestant geword. Hy het 'n wrede dood tydens die sogenaamde Bartolomeusnag gesterf. Sy denke is veral oorheers deur die idee dat die Retoriek en die Logika die wyse is waarop die Skrif uitgelê moet word: alle diskussie oor godsdienstige sake behoort op die beginsels daarvan plaas te vind (Turner, 2007).

$5 \quad$ Hy het egter nie sy studies onder Beza voltooi nie, aangesien Beza nie Arminius se aanhang en propagering van Ramus se denke goedgekeur het nie (d'Assonville, 1992:165). 
opvolger van Calvyn in Genève studeer. In 1588 is hy as predikant te Amsterdam bevestig (d'Assonville, 1992:165).

By die bestudering van die geskrifte van Dirck Volckaertszoon Coornhert ${ }^{6}$ vind hy laasgenoemde se standpunte sterker as sy eie Calvinistiese oortuigings. Hy begin om die leer van die vrye wil en die algemene genade te verkondig. Hierdie leer bring hom in direkte konflik met 'n mede-predikant en latere mede-hoogleraar, Franciscus Gomarus (1563-1645).

In 1602 is hy as professor in Teologie te Leiden aangestel, nieteenstaande die besware van Gomarus. Wtenbogaert, die hofprediker, het ' $n$ volgeling van Arminius geword. Arminius het 'n eie teologie ontwikkel wat ' $n$ sterk invloed op die regering in die Nederlande gehad het (d'Assonville, 1992:166).

Arminius het die regering versoek om 'n spesiale sinode byeen te roep. Die doel was juis om sy teologie die amptelike teologie van die Nederlande te maak en dat die Heidelbergse Kategismus nie meer die belydenis van die kerke sou wees nie (d'Assonville, 1992:167). Hy het egter voor die sitting van die sinode gesterf (Schaff, 2004). In wese was Arminius 'n navolger van Pelagius (Berkhof, 1975:150).

Simon Episcopius (1583-1644) het Arminius as hoogleraar opgevolg. Janus Wtenbogaert (1557-1644) het die hofprediker van prins Mauritz geword en ook die nuwe leier van die Remonstrante. Ander oortuigde Remonstrante was Johannes van Oldenbarnevelt (15491619) en Hugo Grotius (1583-1645) (Schaff, 2004).

Op 14 Januarie 1610 het 43 predikante, aanhangers van Arminius, vergader. Aangesien hulle nie die Kategismus wou onderskryf nie, het hulle 'n eie belydenis vir die State-Generaal opgestel. Hulle het hierdie dokument die "Remonstrantie" (verweerskrif) genoem (Tideman, 1897:22). Oldenbarnevelt het hom aan die kant van die Remonstrante geskaar (d'Assonville, 1992:169). Van hierdie oomblik af is die terme Remonstrante en Arminiane as sinonieme gebruik.

In die noordelike Europese lande, maar veral in die Nederlande, was daar dus drie godsdienstige groeperings, elkeen met hulle eie, unieke agtergrond:

6 Hy leef van 1522 tot 29 Oktober 1590 en was 'n politikus en teoloog in Nederland. Hy het onder andere die Nuwe Testament gedeeltelik in Nederlands vertaal en het die inhoud van die Heidelbergse Kategismus fel gekritiseer. 
- Die Rooms-Katolieke Kerk met sterk tradisies en kerklike struktuur en 'n sterk invloed op talle staatsleiers.

- Die gereformeerdes wat in vrede met die staat wou leef en sterk appèl gemaak het op die Skrif alleen (sola Scriptura) en dat die belydenis aan die Skrif getoets kan en moet word.

- Die Remonstrante wat onder invloed van die Humanisme en Anabaptiste gepreek het dat die mens die vrye wil het om vir of teen God te kies. Hoewel hulle nie anti-konfessioneel was nie, wou hulle slegs die Bybel as Woord van God gebruik.

Die sinode van Dordrecht het 101 jaar na die verskyning van Martin Luther se 95 stellings teen die Rooms-Katolieke Kerk plaasgevind. In hierdie 101 jaar het daar kerkhistories baie gebeur: 'n skeuring in die kerk, die Reformasie, die Kontra-Reformasie en baie politieke woelinge tussen kerk en staat.

\subsection{Dordrecht en die Metodisme}

Die sinode van Dordrecht het nie die teologie van die Remonstrante in so ' $n$ mate besweer dat dit nie verder gepreek is nie. Remonstrantisme het steeds bly voortbestaan naas die gereformeerde leer en ander godsdiensbewegings. Die agtiende eeu in Europa is deur geestelike doodsheid gekenmerk (Van der Vyver, 1975:3). Ook in Amerika was hierdie doodsheid opmerklik (LC, 2006).

Die sinode van Dordrecht (1618-1619) het die Remonstrante vanuit die Skrif geantwoord. Hierdie antwoord (die Dordtse Leerreëls) is egter nie deur die Remonstrante aanvaar nie en 'n verlossingsleer naas dié van die Rooms-Katolisisme en die Calvinisme het ontstaan.

Mbennah en Vorster (1998:175) dui oortuigend aan dat die Rasionalisme in Engeland in die agtiende eeu 'n baie groot rol in die godsdiens gespeel het. John Wesley (1703-1790) se vader en grootvader was teoloë, maar het bande met die staatskerk verbreek. Wesley se grootvader aan moederskant is ook uit die staatskerk geban (Du Toit, 1977:141).

Wesley het aan die Oxford Universiteit studeer en is as priester georden (Van der Vyver, 1975:4). In sy soeke na vrede met God het hy onder andere die mistiek en askese bestudeer, met die "beginsel 
van repristinasie" 7 te doen gekry, asook die geskrifte van Thomas a'Kempis (veral sy De imitatione Christi), Jeremy Taylor (1613-1667) en William Law (1686-1761) (Du Toit, 1977:142).

Tydens 'n besoek aan Amerika het Wesley tot bekering gekom. Hy het daar sendingwerk gedoen, maar tot die besef van 'n dieper ervaring van sy geestelike lewe gekom (Van der Vyver, 1975:7). Wesley het die uitverkiesingsleer verwerp soos Calvyn dit geleer het. Hy het geglo dat dit God se wil is dat alle mense gered word en dat hy die taak het om die evangelie aan alle mense te verkondig sodat hulle gered kan word. Uiteindelik is die kern van sy prediking dat die mens regverdig word deur geloof. Geloof hou in dat die sondaar metodies sy sonde besef en hom deur 'n proses bekeer en dan in oorgawe vir die Here leef (Mbennah \& Vorster, 1998:180). John Wesley het die Metodiste Kerk gestig en kan tereg die vader van die Metodisme genoem word (Renwick, 1973:168).

Met al die invloede op Wesley is daar in sy teologie baie duidelik die spore van Pelagius en die Anabaptisme; hy kon hom nie van die vrye wil van die mens losmaak nie (Berkhof, 1975:155).

George Whitefield (1714-1770) het 'n besonder moeilike jeug gehad as die seun van 'n weduwee wat by 'n taverne gewerk het. Hy was begaafd, maar kon nie self vir sy studies betaal nie. Hy het by Oxford Universiteit as 'n "servitor" 8 studeer. Daar het hy met die Wesley broers, John en Charles, kennis gemaak. Hy het by die "vereniging" van Wesley aangesluit (Answers.com, 2006). In hulle Bybelstudie het hy Serious call van William Law en Imitatio Christi van Augustinus bestudeer. Hy het, veral oor sy sonde, 'n besondere sielewroeging gehad, maar na sy "nuwe geboorte" hom vir sendingwerk beywer (Du Toit, 1977:147).

Whitefield het van Wesley verskil, maar hy was so erg teen Calvyn se standpunt (uitverkiesing en die bewaring van die uitverkorenes) gekant, dat hy eerder 'n ateïs of deïs genoem sou wou word (Mbennah \& Vorster, 1998:182). Whitefield het sewe besoeke aan Amerika gebring en aldaar deel van 'n baie groot herlewingsveldtog uitgemaak (LC, 2006).

7 Reprintinasie is om na die eerste of primitiewe vorm van 'n saak terug te keer. Wesley wou teruggaan na die eerste kerk - die kerk voordat daar enige beïnvloeding was.

8 Hy het allerhande sleurwerkies teen betaling vir die meer gegoede studente gedoen. 
Whitefield se prediking was Remonstrants (Renwick, 1973:168). Die temas van sy preke was die bekering van die mens, dat die mens God nie moet kwaad maak nie en die nuwe geboorte. Uiteindelik het hy ook die gevestigde kerke uit die Reformasie uitgedaag om die dogma te verdedig en hulle dogma te laat vaar om deel te word van die herlewing (LC, 2006).

Tydens die tweede Great Awakening het dit gebeur dat mense hulle tot die bestaande kerke gewend het. Daar het egter ook nuwe gelowe en kerke ontstaan. Een hiervan was in 1830 die Kerk van Jesus Christus van die Heiliges van die Laaste Dae.

Joseph Smith, Sidney Rigdon en Oliver Cowdrey, die drie stigters van die Kerk van Jesus Christus van die Heiliges van die Laaste Dae, het in die gees van herlewing grootgeword, met die Metodisme van Wesley sterk op die voorgrond - 'n Metodisme wat sterk Remonstrants was. Van die eerste lede van die kerk was inderdaad 'n predikant van die Metodiste kerk, John P. Greene (LDS, 1995b:32, 33).

Mormonisme het spesifiek aan die begin van die negentiende eeu ontstaan om die ideale van hierdie tydvak te akkommodeer: persoonlike geestelike hervorming, perfeksionisme, kommunalisme, millennialisme en ekstremisme (Samples et al., 1994:122).

\subsection{Die godsdienstige agtergrond van die godsdiensbewegings in Amerika}

Om die opkoms van kultes in die negentiende eeu in die VSA reg te verstaan, moet gekyk word na die godsdienstige agtergrond van die land in die agtiende eeu. Dit kan weer nie losgemaak word van die godsdienstige gebeure in die sewentiende eeu, veral in Europa, nie.

In die VSA was daar vier groot godsdienstige veldtogte, die sogenaamde Great Awakenings.

Die First Awakening het van 1730-1740 plaasgevind onder aanvoering van Jonathan Edwards. Sy tema was: "Sondaars in die hande van 'n woedende God" (LC, 2006). Hoewel hy Calvinisties was, was sy aanpak dié van die gevoelsgodsdiens. George Whitefield het by hierdie veldtog aangesluit en met groot sukses gepreek. Groot klem is op persoonlike Bybelstudie gelê. Daar was ook die idee dat in die Amerikas (Noord en Suid) die New Light opgegaan het, in vergelyking met die Europese Old Light (Encyclopedia Brittanica, 2007). 
Die Second Awakening het tussen 1820 en 1830 plaasgevind. Daar was toe 'n sterk beweging van die Metodiste en die Presbiteriaanse groepe. Dit het in New England begin en het die sogenaamde "Wilde Weste" as teiken gehad. Drie groot kultegroepe het hulle oorsprong in hierdie tyd gehad, naamlik die Christian Church (Disciples of Christ), die Cumberland Presbyterians en die Kerk van Jesus Christus van die Heiliges van die Laaste Dae (Encyclopedia Brittanica, 2007).

Daar was ook 'n Third Awakening (1858-1905) en 'n Fourth Awakening (1965-1975).

\section{Mormonisme: teologiese agtergrond}

Daar was drie vername rolspelers in die stigting van die Kerk van Jesus Christus van die Heiliges van die Laaste Dae, naamlik Joseph Smith (jnr.), Sidney Rigdon en Oliver Cowdrey. Die ouers van Joseph Smith, stigter van die Kerk van Jesus Christus van die Heiliges van die Laaste Dae, was lidmate van die Metodiste kerk in die staat New York (LDS, 1995a:8).

Joseph Smith (jr) is op 23 Desember 1805 te Sharon in die staat Vermont gebore. Die gesin het in 1816 na Palmyra, Ontario in die staat New York verhuis. In 1820 het verskillende denominasies (veral die Metodiste, Presbiteriane en die Baptiste) herlewingsveldtogte in die staat New York geloods (Richards, 1979:7). As jong seun was Joseph verward oor watter godsdiens die regte sou wees. $\mathrm{Na}$ aanleiding van Jakobus 1:5 het hy om wysheid gebid en in die bos naby sy tuiste het twee Persone, die Vader en die Seun, aan hom verskyn en aan hom geopenbaar dat hy die profeet is wat gekies is om die kerk te herstel (LDS, 1995b:4).

Mormoonse bronne beweer dat die Vader, Jesus Christus en verskeie engele aan Joseph Smith in die woud naby die huis van sy ouers in 1820 verskyn het (die sg. "eerste verskyning"). In 1823 het die engel Moroni 9 aan Joseph Smith verskyn om hom in te lig dat daar in 400 n.C. sekere goue plate versteek is en dat hy, Joseph Smith, gekies is om die plate te vertaal en aan die wêreld bekend te

9 Moroni, die skrywer van die goue plate, was die seun van Mormon (Woorde van Mormon 1:1) en die laaste profeet van die Nefiete, voor hulle deur die Lamaniete uitgemoor is. Hy het uit die dood "opgestaan" en is tot 'n engel verhoog. Hy moes aan Joseph Smith wys waar hy die plate begrawe het, sodat Smith dit kon vertaal (L\&V, 1981:128:20). 
stel. Hy moes die vertaalwerk deur middel van die Urim en Tummim 10 doen (Richards, 1979:69).

Op 6 April 1830 het Joseph Smith saam met vyf ander die Kerk van Jesus Christus te Fayette, New York gestig. Deur 'n goddelike openbaring is Joseph Smith as die leier en eerste profeet aangewys (LDS, 1995b:32).

In die volgende jare is aktief sending gedoen en die kerk het gegroei. Sending is nie net in die Amerikas gedoen nie, maar ook in Engeland. Tempels is eers in Kirtland, daarna in Missouri, Nauvoo en daarna op ander plekke in Amerika gebou. Oral het die leerstellings teenkanting ontvang en is hulle "uitgedryf te midde van verskriklike vervolging" (LDS, 1995a:36).

In 1833 het hy 'n profeteskool vir opleiding in die kerk gestig. In Februarie 1841 is hy as luitenant-generaal van die Nauvoo-legioen ingesweer. In 1842 is hy as die besturende redakteur van die Times and Seasons koerant en later die jaar as burgemeester van Nauvoo gekies (Anon., 2006).

Vroeg in 1844 kondig hy aan dat hy as kandidaat staan vir die verkiesing van die president van die VSA. Sy adjunk sou Sidney Rigdon wees. Hy is egter voor die presidentsverkiesing vermoor (Answers.com, 2006).

Sidney Rigdon was 'n pastoor in die First Baptist Church in Library, voordat hy in 1823 afgesit is uit die amp. Hy het naamlik geweier om die Philadelphia Confession of Faith - die belydenis van die kerk te onderteken of te preek (Davis et al., 1980:93). Rigdon het egter toegang tot dokumente gehad wat 'n baie belangrike rol gespeel het in die Mormoonse teologie: die boeke van Solomon Spalding. 11

10 Richards (1979:69) dui die direkte verband aan met die Urim en Tummim wat deur die hoëpriester gedra is om te gebruik by beslissings wat gemaak moes word. Hy beweer dat dit die twee stene is wat saam met die goue plate aan Joseph Smith gegee is. Die beskrywing wat Joseph Smith van die gebruik van die Urim en Tummim gee (BKP, 1981:51), verskil egter van die Bybelse weergawe: Smith gebruik dit as "openbaarders" van die wil van God in die "vertaling" van die goue plate, terwyl dit in die Bybel konsekwent gebruik word om 'n beslissing van die Here te vra (Eks. 28:30; Lev. 8:8; Num. 27:21; Deut. 33:8; 1 Sam. 28:6; Esra 2:63 en Neh. 7:65).

11 Die spelling word soms as Spaulding aangegee. 
Spalding (1761-1816) was 'n skrander student en het eers regte en daarna teologie studeer (Davis et al., 1980:29). Hy het egter nie voltyds as predikant opgetree nie as gevolg van swak gesondheid (Davis et al., 1980:30). Spalding het verskeie boeke oor die vroeë geskiedenis van die Amerikas probeer skryf (Davis et al., 1980:31).

Een tweede manuskrip, Manuscript found, het hy aan verskeie mense voorgelees (Davis et al., 1980:39, 41, 42,43). In ongeveer 1812 het Spalding Manuscript found aan 'n uitgewer in Pittsburgh gegee om te publiseer. Die manuskrip was lank by die drukker. Een van die werknemers was Sidney Rigdon (Davis et al., 1980:45). In ongeveer 1828, lank na Spalding se dood, het hulle ontdek dat die manuskrip van Manuscript found verlore geraak het (Davis et al., 1980:55). Uit die getuienis van verskeie mense blyk dit dat daar selfs meer manuskripte kon gewees het. Joseph Miller praat van 'n manuskrip, Lost history found - lost manuscript (Davis et al., 1980:77).

Wat egter opval, is dat al die verwysings na hierdie manuskrip sekere elemente bevat:

- Dit bevat die geskiedenis van die inwoners van Amerika vóór die koms van die Europeërs en is aan die verlore stamme van Israel gekoppel.

- Die name Lamaniete en Nefiete is deur Spalding gebruik.

- Hierdie geskiedenis is opgeskryf en begrawe.

Rigdon het dus nie net toegang tot die werke van Spalding gehad nie, maar het ook 'n sterk teologiese agtergrond gehad. Hierdie dogma vind duidelik vergestalting in die teologie van Joseph Smith. Die Boek van Mormon het baie sterk elemente van die werke van Spalding en Rigdon se oortuiging dat die mens die vrye wil het om sy verlossing self te bewerk.

Oliver Cowdrey was 'n onderwyser wat tussen 1820 en 1829 gereeld die Smith-huis besoek het. Hy en Joseph Smith het mekaar gedoop (Martin, 1997:187). Cowdrey was betrokke by die kerk van Ethan Smith (1762-1849), skrywer van die boek View of the Hebrews ('n moontlike bron van die Boek van Mormon) en predikant van Cowdrey se familie.

Daar word nou vervolgens na die agtergrond gekyk waarteen die Kerk van Jesus Christus van die Heiliges van die Laaste Dae ontstaan het, die definisie van 'n kulte en waarom hierdie studie juis hierdie organisasie as 'n kulte identifiseer. 


\subsection{Mormoonse teologie}

'n Kenmerk van kultes is dat die dogma oor aspekte van hulle dogma verander namate hulle "nuwe lig" ontvang. Hier sal aangetoon word dat dit inderdaad by die belydenis van die Kerk van Jesus Christus van die Heiliges van die Laaste Dae gebeur het. In die teologie word die Bybel gebruik, maar ondergeskik gestel aan die Boek van Mormon en die openbarings van Joseph Smith.

Die 13 Artikels van geloof is die basis vir die dogma van die Kerk van Jesus Christus van die Heiliges van die Laaste Dae. Hoewel al die artikels van belang is in die bestudering van die Mormone, is alles nie van belang vir hierdie artikel nie.

Slegs drie van die artikels word uitgelig, naamlik watter mense God verlos, hoe die mens verlos word en hoe die mens weet hoe hy verlos word.

\subsubsection{Artikel 1}

Hoewel die Mormone die Bybel as woord van God aanvaar, 12 het hulle 'n tweede openbaring naas die Bybel, naamlik die Boek van Mormon. Die logiese gevolgtrekking waartoe gekom kan word, is dat dieselfde God gedien word soos Hy Homself in die Bybel openbaar. Dit is egter nie waar nie, aangesien drie afsonderlike gode onderskei word, naamlik 'n Vader van vlees en been, 'n Jesus Christus en 'n heilige gees.

\subsubsection{Artikel 3: Verlossing}

Hierdie artikel bely dat Christus gesterf het, maar dat die mens ook sekere vereistes moet nakom vir sy saligheid. Die praktiese uitwerking van hierdie artikel word in die volgende dokumente geïllustreer:

- Die plan van saligheid is 'n pamflet wat die Mormone uitgee wanneer hulle evangelisasiewerk doen. In hierdie werk (Morgan, 1881:21-23) word die besef van die sonde en God se oordeel oor die sonde bespreek. Daar word sterk klem gelê op die straf van die sonde, maar nie een keer word daar verwys na die soendood van Christus om die sondes kwyt te skeld nie. 
- Doctrines of the gospel (LDS, 2000:22-26) lê in die hoofstuk oor die versoeningswerk van Christus sterk klem op die nakoming van die wet. Dit bevat die volgende fasette:

- Sonde is die doelbewuste ongehoorsaamheid van die mens. God se regverdigheid vereis die straf van elke sonde. Aangesien die mens sonde doen, is hy onderworpe aan die regspraak van God.

- Almal sou, as dit nie vir die versoening van Christus was nie, ewig geestelik en fisies moes ly. Almal sou daardeur onderdane van die duiwel bly.

- Slegs Christus het die kwalifikasies en eienskappe besit om ewige versoening te bewerkstellig. Hy erf die kapasiteit om te ly en te sterf van die Vader. Hy was vry van persoonlike sonde en het mag oor die dood gehad.

- Deur hierdie krag en eienskappe het Jesus die onbeperkte en ewige versoening bewerkstellig. Jesus onderwerp hom aan die Vader in die versoening. Die versoening is 'n liefdesdaad van die Vader en die Seun. Die versoening begin in Getsemane en eindig in die leë graf. Jesus verneder Hom onder alle dinge om die versoening te bewerk en sy lyde was meer as wat enige sterflike wese kon dra. Hierdie ewige versoening is geldend vir alle wêrelddele en sal al God se kinders red (behalwe die seuns van verderf).

- Die versoening van Christus bring die wette van regverdigheid en genade in harmonie met mekaar. Genade wis nie geregtigheid uit nie. Geregtigheid word deur die versoening bereik en dit laat die siel van die mens toe om gereinig te word deur bekering. Jesus staan in vir die mens vir die vereistes van geregtigheid.

- Die versoening van Christus is noodsaaklik vir die verlossing van die kinders van God. Christus oorwin die fisiese dood om die opstanding van sy kinders te verseker. Sy dood en lyde maak dit vir die mens moontlik om die ewige straf te oorwin indien die mens hom bekeer. Die versoening van Christus maak dit vir alle mense moontlik om voor God te verskyn om geoordeel te word.

- Alle mense moet die wil van die Vader en die Seun doen om die volle voordeel van die versoening te ontvang. Die Verlosser het gekom om almal te red wat aan hom gehoorsaam is. Wie nie God se gebooie onderhou nie, moet ly vir hulle eie 
sonde. Genade word verleen aan diegene wat God se gebooie onderhou.

- True to the faith (LDS, 2004:14-20). Hierdie boek stem grootliks ooreen met Doctrines of the gospel. Die volgende word addisioneel vermeld:

- 'n Universele verlossing. Alle mense wat ooit op die aarde geleef het, sal in die teenwoordigheid van God met verheerlikte liggame leef.

- Die mens word onvoorwaardelik verlos van die effek van die sondeval, maar is aanspreeklik vir die sondes wat die mens self doen.

- Om die ewige lewe te bereik, moet die mens aan sekere voorwaardes voldoen. Dit sluit geloof, bekering en volharding in. Die volgende ordinansies van verlossing moet ontvang word: doop, gawe van die Heilige Gees, georden as priester volgens die orde van Melgisedek (mans), tempelgawes en tempelhuwelike.

Indien hierdie uitsprake deeglik bestudeer word, moet daar besef word dat dit 'n groot aantal halwe waarhede bevat: daar word wel bely dat Christus die enigste Verlosser is en dat Hy die dood oorwin het.

'n Halwe waarheid bevat egter volle leuens:

- Die lyde van Christus word beperk tot die tyd tussen Donderdagaand in Getsemane en Sondagoggend wanneer Jesus opstaan. In die gereformeerde dogma word bely dat sy hele lewe op aarde 'n lyde was (Heidelbergse Kategismus Sondag 15, 2003). Hy was immers sy hele lewe sonder sonde en het geleef in 'n gebroke sondige wêreld. Verder was sy totale lewe tot en met sy begrafnis 'n vernedering.

- Christus se dood alleen is nie voldoende vir die verlossing van die mens nie. Die mens moet aan God eers bewys dat hy waardig is om verlos te word.

- Die mens moes sy hele lewe volhardend leef om aan God sy getrouheid te wys - en kan dus nie in volle oorgawe die woorde van Efesiërs 2:8, 9 sê nie: "Want uit genade is julle gered, deur die geloof en dit nie uit julleself nie: dit is die gawe van God; nie uit die werke nie, sodat niemand mag roem nie." 
- 'n Universele verlossing word verkondig. Almal word gered. Die verskil tussen alle geredde mense is egter (vir die Mormone) die tipe koninkryk wat die mens sal ingaan (LDS, 2004:92-94).

- Daar is wel 'n hel, maar daar moet telkens onderskei word watter hel ter sprake is (LDS, 2004:81).

Die verlossing van sonde lê volgens die Mormone nie by God alleen nie. Die kruisdood van Christus speel in die beredenering oor die vergewing van sonde 'n baie klein rol.

Daar is dus weinig raakpunte tussen die Mormoonse en gereformeerde leer aangaande die vergifnis van sonde. Die oënskynlike ooreenkoms word totaal en al weerspreek in die res van die dogma. Die verlossing berus daarom by die vrye wil van die mens en nie uitsluitlik by die soendood van Christus nie.

\subsubsection{Artikel 4: Verlossing}

Artikel 4 beskryf die wyse waarop die mens verlos word. Dit geskied in vier stappe en word vervolgens bespreek.

\subsubsection{Geloof}

In die evangelisasie-pamflet van die Kerk van Jesus Christus van die Heiliges van die Laaste Dae word geloof as 'n noodsaaklike komponent vir die saligheid uitgespel, maar binne 'n bepaalde konteks (Morgan, 1881:10): "Geen mens kan iets doen as hy nie die geloof het dat dit wel gedoen kan word nie. ... So sou niemand ook enige aanbod van God opvolg as hy nie glo dat gehoorsaamheid daaraan seëninge sal meebring nie." Die volgende drie stellings word onder andere gemaak:

- Die doel van die geloof is om God te behaag (Heb. 11:6). Geloof is om iets aan te pas in die verwagting dat dit vir die mens goeie resultate sal oplewer.

- Die mens beroof homself vandag van 'n menigte groot en kosbare seëninge deurdat hulle nie soos die Mormone glo nie.

- Die mens moet nie aan tekens vashou om die geloof te verkry nie. Die gelowige sal tekens doen omdat hy die geloof het (Mark. 16:17, 18).

Dit is opvallend dat hier weereens sterk sprake is van die vrye wil van die mens: God maak bloot 'n aanbod wat die mens kan aanvaar 
as hy die seëninge wil ontvang; en geloof is nie die aksie van God nie, maar 'n aksie van die mens.

Wanneer die Mormone bely dat hulle in Christus glo (Artikel 4 van die Belydenis) en dat dit beteken dat hulle volkome op Hom moet vertrou, moet presies vasgestel word wat daarmee bedoel word. Hulle spesifiseer hierdie vertroue deur die volgende te noem (LDS, 2004:54):

- vertrou Christus se onbeperkte mag, intelligensie en liefde;

- glo dit wat Christus leer;

- alhoewel die mens nie alles verstaan wat gebeur nie, verstaan Christus wel;

- 'n mens moet onthou dat Christus al die mens se pyn, beproewings en gebreke gely het en dat Hy weet om die mens te help om bo sy daaglikse probleme uit te styg;

- Hy het die wêreld oorwin en het die weg berei sodat die mens die ewige lewe kan ontvang;

- Hy is altyd gereed om die mens te help.

Dit is belangrik om daarop te let dat daar geen melding gemaak word van die versoeningsdood van Jesus Christus soos wat in die Heidelbergse Kategismus gedoen word nie. Die Kategismus bely die soendood van Christus as die enigste grond vir die saligheid terwyl die Mormoonse verlossing berus op die vrye wil van die mens.

\subsubsection{Bekering}

Dit is die mens se plig en opdrag om hom te bekeer. Dit beteken nie bloot om berou te hê oor sonde nie, maar dit is die werklike lewensverandering (Morgan, 1881:12).

\section{- Noodsaaklikheid}

Bekering is noodsaaklik omdat niks onreins die koninkryk van die hemel kan beërwe nie. Sonde het vir die Mormone twee basiese betekenisse, naamlik om bewustelik die wet van God ongehoorsaam te wees en om te versuim om reg op te tree as die mens kennis van die waarheid het (LDS, 2004:163).

Sonde maak die mens vuil en onwaardig om in die teenwoordigheid van die hemelse Vader te verskyn. Verder bring dit ook foltering vir die siel in hierdie lewe (LDS, 2004:132). 
Hulle bely wel dat Jesus se versoening by die Vader die enigste wyse is waarom bekering moontlik gemaak word: omdat (kursivering - HFvW) Jesus Christus gely het om die straf vir die sonde te dra, kan (kursivering - HFvW) die mens vergewe word as hy hom waarlik bekeer. In die proses van bekering moet die mens net op sy genadige vergewing vertrou en die mens sal van sy sonde gereinig word (LDS, 2004:133).

\section{- Elemente van bekering}

- Geloof in die hemelse Vader en Jesus Christus: die mens moet hom tot sy hemelse Vader wend en bid vir geloof. Die hemelse Vader is altyd gewillig om te luister as die mens na Hom kom met 'n verootmoedigde hart. Dit is 'n geloofsdaad in Jesus Christus - 'n erkenning van die krag van sy versoening (LDS, 2004:134).

- Berou oor die sonde: die mens moet aan homself sy sonde erken, sodat dit kan lei tot die bekering wat red. Die mens moet besef dat hy sy hemelse Vader en die Verlosser teleur gestel het en hy moet bereid wees om alle eise na te kom wat vir die bekering verwag word (LDS, 2004:134).

- Belydenis van die sonde: die mens moet al sy sonde voor die hemelse Vader uitstort. Ernstige sonde kan die lidmaatskap van die kerk in gedrang bring en dit sal meebring dat die sonde ook aan die leierskap van die kerk bely moet word. Die biskop/sendingpresident is die bewaker en die regter in die kerk (LDS, 2004:134).

- Ophou sonde doen: belydenis alleen is nie voldoende nie - die mens moet die punt bereik waar hy nie weer die sonde doen nie.

- Die mens het die plig om dit reg te stel wat deur die sonde geskend is. Dit is dan ook vir die Here die teken dat jy alles in jou vermoë doen om jou te bekeer (LDS, 2004:135).

- Regverdige lewe: die mens moet sy lewe met 'n goeie en regverdige leefwyse vul.

Bekering is dus vir die Mormone uitsluitlik 'n wilsbesluit van die mens omdat hy die vryheid daartoe het. 


\section{- Evaluering}

Wanneer hierdie beskrywing van die elemente van bekering gelees word, lyk dit op die oog af of dit nie veel verskil van die belydenis van die Heidelbergse Kategismus Sondag 33 (2003:59) nie.

Die Dordtse Leerreëls, veral Hoofstuk 5, lê sterk klem op die feit dat die gevolg van die bekering die volharding van die gelowiges is. Hulle kan in sonde val, maar as hulle hulle bekeer, het hulle van harte berou oor die sonde en begeer vergifnis deur die soenverdienste van Christus (Hoofstuk 5:7). Die uitverkorenes kan verder ook geloofsekerheid hê op grond van God se onveranderlike wil (Hoofstuk 5:8, 9).

Daar is ook ' $n$ ander belangrike verskil: die Heidelbergse Kategismus stel dat die doel van die bekering dankbaarheid van die gelowige vir sy verlossing is, terwyl die doel van die bekering by die Mormone is om die godheid te beïndruk en sodat die mens sy eie verlossing bewerk.

\section{Slot}

Daar is nie in hierdie artikel aangetoon waarom die Mormone 'n kulte is nie. In die verlossingsleer soos Joseph Smith dit geformuleer het, is dit egter geen nuwe teologie of openbaring nie. Die prediking van Pelagius was die prediking van die Anabaptiste. Die Anabaptiste het weer sterk na vore getree tydens die Reformasie en die boodskap van die vrye wil van die mense het sy neerslag gevind in die teologie van die Remonstrante. Wesley het ook hierdie verlossingsboodskap gekies tydens sy evangelisasieveldtog in die VSA.

Tydens hierdie veldtog het Sidney Rigdon 'n prediker geword van die boodskap van die vrye wil van die mens om verlos te word. Joseph Smith soek die ware kerk, en saam met Rigdon word die Kerk van Jesus Christus van die Heiliges van die Laaste dae gestig met die boodskap: alle mense kan verlos word. Elkeen het die vrye wil om by die Mormone aan te sluit. Die Mormone glo en preek dat hulle die enigste ware kerk is - herstig soos Jesus Christus dit oorspronklik bedoel het.

\section{Geraadpleegde bronne}

ANDERSON, S.E. 2006. The first Baptist. Chapter 8: Tragically ignored. http://www.pbministries.org/History/S.\%20E.\%20Anderson/the_first_baptis t08.htm Date of access: 29 Nov. 2006. 
ANON. 2006. Joseph Smith's achievements. http://www.josephsmithjr.com/ achievements.htm Date of access: 21 Sept. 2006.

ANSWERS.COM. 2006. George Whitefield. http://www.answers.com/topic/ george-whitefield Date of access: 17 Dec. 2006.

BERKHOF, L. 1975. The history of Christian doctrines. Edinburgh: Banner of Truth.

BERKHOUWER, G.C. \& TOORNVLIET, G., eds. 1949. Het dogma der kerk. Groningen: Jan Haan.

BIGGS, W.W. 1965. Introduction to the history of the Christian church. London: Arnold.

BOSMAN, H.L. 1987. Die Nederlandse Geloofsbelydenis: ontstaan, Skrifgebruik en gebruik. Pretoria: Unisa.

CALVYN, J. 1986. Institusie van die Christelike godsdiens. DI. 2. Vert. deur H.W. Simpson. Potchefstroom: Calvyn Jubileumboekefonds.

CALVYN, J. 1988. Institusie van die Christelike godsdiens. DI. 3. Vert. deur H.W. Simpson. Potchefstroom: Calvyn Jubileumboekefonds.

CEREGHIN, J. 2006. In defense of Erasmus. http://watch.pair.com/erasmus. html Date of access: 14 Mar. 2006.

CHURCH OF JESUS CHRIST OF LATTER-DAY SAINTS. 1995a. Our heritage: a brief history of the church of Jesus Christ of latter-day saints. Salt Lake City.

CHURCH OF JESUS CHRIST OF LATTER-DAY SAINTS. 1995b. Truth restored: a short history of the church of Jesus Christ of latter-day saints. Salt Lake City.

CHURCH OF JESUS CHRIST OF LATTER-DAY SAINTS. 2000. Doctrines of the gospel: student manual - Religion 430 and 431. Salt Lake City.

CHURCH OF JESUS CHRIST OF LATTER-DAY SAINTS. 2004. True to the faith: a gospel reference. Salt Lake City.

D'ASSONVILLE, V.E. 1992. Gids vir kerkgeskiedenis. Marnix: Potchefstroom.

DAVIS, H.A., SCALES, D.R. \& COWDREY, W.L. 1980. Who really wrote the book of Mormon? California: Vision House.

DE JONG, O.J. 1980. Geschiedenis der kerk. Nijkerk: Callenbach.

DEN BOER, W.A. 2004. Nederlandse gereformeerde theologie op weg naar de synode van Dordrecht 1618-1619. Apeldoorn: Theologische Universiteit Apeldoorn. (Doctoraalscriptie - ongepubliceerd.)

DU TOIT, J.D. 1977. Die Metodisme. (In Du Toit, J.D. Versamelde werke van Totius. DI. 6: Strominge. Kaapstad: Tafelberg. p. 129-214.)

ELLIOTT, R. 2005. Textus receptus. http://www.skypoint.com/ waltzmn/TR. html Date of access: 14 Mar. 2006.

ENCYCLOPEDIA BRITTANICA. 2007. Great awakening. (In Encyclopædia Britannica 2007 Ultimate reference suite.) [DVD-ROM].

ESTEP, W.R. 1975. The Anabaptist story. Grand Rapids: Eerdmans.

GAMEO

see GLOBAL ANABAPTIST MENNONITE ENCYCLOPEDIA ONLINE

GLOBAL ANABAPTIST MENNONITE ENCYCLOPEDIA ONLINE. 2006. Schleitheim Confession (Anabaptist 1527): a GAMEO Source document. http://www.gameo.org/index.asp?content=http://www.gameo.org/ HAT encyclopedia/contents/s345.html Date of access: 30 Jun. 2006.

kyk VERKLARENDE HANDWOORDEBOEK VAN DIE AFRIKAANSE TAAL 
HEIDELBERGSE KATEGISMUS. 2003. (In Psalmboek: die berymde en omgedigte Psalms en ander Skrifberymings in gebruik by die Gereformeerde Kerke in Suid-Afrika. Paarl: NG Kerkuitgewers. p. 33-72.)

KERK VAN JESUS CHRISTUS VAN DIE HEILIGES VAN DIE LAASE DAE. 1981. Die leer en verbonde van die Kerk van Jesus Christus van die Heiliges van die Laaste Dae; en, Die baie kosbare pêrel. Salt Lake City.

L\&V

kyk KERK VAN JESUS CHRISTUS VAN DIE HEILIGES VAN DIE LAASE DAE

LC

see LIBRARY OF CONGRESS

LDS

see CHURCH OF JESUS CHRIST OF LATTER-DAY SAINTS

LIBRARY OF CONGRESS. Exhibition. 2006. Religion in eighteenth-century America. http://www.loc.gov/exhibits/religion/rel02.html Date of access: 26 Jun. 2006.

LINDSAY, T.M. 1964. A history of the Reformation in two volumes. Vol. 2: The Reformation in Switzerland, France, the Netherlands, Scotland and England - the Anabaptist and Socinian movements: the counterReformation. Edinburgh: Clark.

LITTELL, F.H. 1952. The origins of sectarian Protestantism: a study of the Anabaptist view of the church. London: MacMillan.

MARTIN, W. 1997. The kingdom of the cults. Minnesota: Bethany House.

MBENNAH, E.O. \& VORSTER, J.M. 1998. The influence of Arminian conception of predestination on the 18th-century Wesleyan revival. Studia historiae ecclesiasticae, 24(1):161-187.

MORGAN, J. 1881. Die plan van saligheid. (Vertaling van: Plan of salvation.) Salt Lake City: Church of Jesus Christ of latter-day saints.

PKB

kyk KERK VAN JESUS CHRISTUS VAN DIE HEILIGES VAN DIE LAASE DAE

RENWICK, A.M. 1973. The story of the church. London: InterVarsity.

RICHARDS, L. 1979. Wonderlik en wonderbaar. Rosebank: Kerk van Jesus Christus van die Heiliges van die Laaste Dae.

SAMPLES, K.R., DE CASTRO, E.M., ABANES, R. \& LYLE, R.J. 1994. Prophets of the apocalypse: David Koresh and other messiahs. Michigan: Baker.

SCHAFF, P., ed. 2004. The Arminian controversy. AD 1604-1619. http://www.ccel.org/ccel/schaff/creeds1.ix.viii.viii.html Date of access: 30 Aug. 2005.

SCHULZE, L.F. 1978. Geloof deur die eeue. Pretoria: NG Kerkboekhandel.

TIDEMAN, B. 1897. Overzicht van de geschiedenis der Remonstranten. Amsterdam: Rogge.

TURNER, W. 2007 [1911]. Peter Ramus. (In Rossi, G., transcriber. The Catholic Encyclopedia. Vol. 12. New York: Robert Appleton. http://www.newadvent.org/cathen/12638b.htm Date of access: 9 Feb. 2008.

VAN DER VYVER, G.C.P. 1975. Die wordingsgeskiedenis van die Metodisme. (In "Revival" of Reformasie? 'n Studie oor Metodisme. Potchefstroom: Pro Rege. p. 1-15.) (Wetenskaplike Bydraes van die PU vir CHO. Reeks A: Geesteswetenskappe, nr. 18.) 
VAN 'T SPIJKER, W. 1987. Voorgeschiedenis. (In Van 't Spijker, W., De Bruin, C.C., Florijn, H., Moerkerken, A. \& Natzijl, H. De synode van Dordrecht in 1618 en 1619. Houten: Den Haartog. p. 11-56.)

VERKLARENDE HANDWOORDEBOEK VAN DIE AFRIKAANSE TAAL. 1988. Johannesburg: Perskor.

\section{Kernbegrippe:}

Anabaptiste

kerk

kulte

Mormone

Remonstrante

verlossing

vrye wil

\section{Key concepts:}

Anabaptist

church

cult

free will

Mormon

Remonstrant

salvation 